\title{
Authors' NOTES
}

JŪRATĖ BARANOVA - Prof. Institute of Educational Sciences, Vilnius University jurabara@gmail.com

JERZY BAGROWICZ - Professor Emeritus, Nicolaus Copernicus University in Toruń

JOANNA CUKRAS-STELĄGOWSKA - PhD, Faculty of Philosophy and Social Sciences, Nicolaus Copernicus University in Toruń joanstel@umk.pl

PIOTR DUBIEL - Department of Family Science, University of Opole piotr.m.dubiel@gmail.com

KAMILLA FREJUSZ - PhD, Pontifical Faculty of Theology in Warsaw, Collegium Bobolanum

kamif@poczta.onet.pl

JAROSŁAW HOROWSKI - Prof., Faculty of Philosophy and Social Sciences, Nicolaus Copernicus University in Toruń

jarohor@umk.pl

GRZEGORZ KARWASZ - Prof., Faculty of Physics, Astronomy and Informatics, Nicolaus Copernicus University in Toruń karwasz@fizyka.umk.pl

ANNA KAMIŃSKA - PhD, Institute of Exact and Technical Sciences, Department of Physics, Pomeranian University anna.kaminska@apsl.edu.pl 
ANGELIKA LENART - Department of General Pedagogy, Faculty of Social Sciences of the John Paul II Catholic University in Lublin nikia12@vp.pl

ZBIGNIEW MAREK - Prof., Ignatianum Academy zmarek23@gmail.com ANNA WALULIK - Prof., Ignatianum Academy walulika@gmail.com 